\title{
An Analysis of Implementation of Islamic School Counseling Strategies in Indonesia to Avoid Fanaticism
}

\section{Diandra Shafira Maharani ${ }^{1}$, Lintang Dwi Aprilia, Muhammad Hudan Raya ${ }^{3}$}

Universitas Islam Negeri Syarif Hidayatullah, Indonesia ${ }^{123}$

diandra.shafira21@mhs.uinjkt.ac.id*

Article Information:

Received September 17, 2021

Revised October 4, 2021

Accepted November 16, 2021

Keywords: Fanaticism, Counseling, Islamic Schools

\section{Abstract}

Tulisan ini mengkaji bentuk - bentuk dan penerapan strategi pencegahan sikap fanatisme di lingkungan sekolah berlatarbelakang Islam. Fanatisme dalam lingkungan sekolah Islam menjadi permasalahan penting yang harus segera disikapi. Objek penelitian ini adalah seluruh tenaga ahli pendidik dari setiap lembaga pendidikan yang sudah berpengalaman dalam mengukur tingkat fanatisme di lingkungan sekolah, dengan jumlah partisipan sebanyak 28 orang sebagai perwakilan dari berbagai institusi pendidikan. Penelitian ini menggunakan metode penelitian kuantitatif dengan pengumpulan data lewat pengisian kuesioner yang disebarkan kepada responden, yang berada di sekitar Pulau Jawa. Setelah data terkumpul, penarikan kesimpulan menggunakan pola pikir deduktif. Hasil kajian berdasarkan pengisian kuesioner dapat disimpulkan bahwa bentuk - bentuk fanatisme dipengaruhi oleh kurangnya perspektif ilmu di masyarakat, pengaruh circle pertemanannya, dan pengaruh mekanisme organisasi sekolah yang diikuti pelajar. Serta penerapan pencegahan fanatisme di lingkungan sekolah Islam dapat dilakukan dengan pendekatan Bimbingan Konseling (BK).

\section{INTRODUCTION}

Based on previous research conducted by (Jubaedah dan Muhammad Misbah, 2021), fanaticism can be found anywhere in underdeveloped or developed countries, in atheist or religious societies, or inlay or educated groups of people. Then to avoid this, they use a strategy by teaching inclusive-multicultural Islam and applying multicultural-inclusive prophetic education. In Another study conducted by (A'yuna and Nurdin 2016), fanaticism is a happy attitude that is expressed excessively. To avoid this attitude, this study uses a psychological strategy, namely employing counselors who invite their clients to think rationally. Subsequent research conducted by (Deko Rio Putra, 2019), fanaticism is a person's belief that is very strong and lacks reason so that he does not accept other ideas, which aim to pursue something that is manifested in emotional and excessive intensity. To prevent this, they use a strategy by increasing tolerance and not discriminating against people who have a different mindset from

E-ISSN:

Published by:

\section{8-3250}

Institut Agama Islam Palu 
the organization we have. According to Hurlock in the research of (Khulafaurosyidin and Setiawati 2013), emotional imbalance and instability in many ways exist during this time. This makes teenagers very vulnerable to the influence of fanaticism because the ability of teenagers to think, judge and believe in perception is sometimes still not objective, so it is not uncommon for teenagers who have problems with lack of confidence, feel lost their identity, lack selfesteem and tend to imitate or imitate. imitating a group or understanding to gain acceptance in a group, both in appearance, perspective, culture, and so on.

Meanwhile, according to research by (Elvi Yanti, 2020) says that fanaticism begins with love for oneself or excessive admiration for oneself, then boasts of the advantages that exist in himself and his group, and at a certain level can develop at a level of dislike. Then it will develop to other people or other groups that are different from him. Then as a solution, this study uses a strategy through group guidance, which later the BK teacher will explain and relate to religious discussions such as "something too much is not good" and explains the negative impacts in it. Then research conducted by ( Aminullah Cik Sohar dan M Randicha Hamandia), fanaticism appears in the form of excessive belief in the teachings they follow. As a solution, this study uses a strategy using a good advice method, namely by giving advice and warning to others by using good language, and the mujdah method, namely by exchanging opinions or arguments by two parties.

However, based on research conducted by (Ibid, 2020) says that fanaticism in this sense is one way to defend oneself and the isolation and loneliness of the soul. One learns that following oneself to the extreme about one particular view or group can bring safety and tranquility to one's soul. His basic human pattern always works, and uses this pattern, namely fanaticism, as something normal and even must be done for self-improvement. Fanaticism is a human phenomenon. So the difference between this study and previous research lies in the placement of the mindset in determining the solution in finding peace of one's soul.

However, based on research conducted by (Herlambang, 2018) self-defense mechanisms are techniques used by individuals to avoid unpleasant things or things that provoke anxiety. There are several main defense mechanisms identified by Freud, one of which is a diversion. Diversion (Feist and Feist, 2010) is the formation of reactions limited to only one single object. In displacement, people can direct inappropriate impulses at some people or objects so that the original impulse is hidden or hidden. So the difference between this study and previous research is the attitude of fanaticism as a way of handling the manifestation of a person's diversion towards alienation and loneliness of the soul. In addition, another study conducted by Herlambang and Boby (2018) that fanaticism is a form of love that is believed to have made a major contribution in life. Fanaticism also means the spirit to pursue a certain goal. So the difference between this study and previous research is the attitude of fanaticism as an effort to fill the alienation and loneliness of the soul. While the difference between previous studies and ours is that our research uses schools with an Islamic background that focus on the causes of fanaticism among students in implementing fanaticism prevention strategies which have been responded to by the educators or school staff concerned. This research is based on a theory that says that fanaticism begins with self-love or excessive self-admiration, then boasts of the advantages that exist in himself and his group, and at a certain level can develop at a level of dislike. Then it will develop to other people or other groups that are different from him. Then as a solution, this study uses the application of Islamic counseling guidance strategies, where BK as a service provided by the agency in explaining and linking discussions such as "something too much is not good" and explains the negative impact it will get.

The author's focus in drawing the title "An Analysis of Implementation of Islamic School Counseling Strategies in Indonesia to Avoid Fanaticism" is that this research focuses on the role of Islamic Counseling Guidance as a form of service in schools as a strategy for preventing fanaticism. Therefore, this research was conducted to minimize the spread of 
fanaticism in the school environment. Because we know that students are very vulnerable in receiving information - information or currents - flows of the surrounding environment. Students are very easily influenced by the thoughts of others because they tend to be still in a period of development and unstable in determining a mature thought. Then the benefits of this research empirically for students, namely being able to open a broad mindset related to forms of fanaticism and increase understanding related to the concept of fanaticism that exists in the surrounding environment to avoid it. For educators, it can minimize the spread of fanaticism and be an encouragement to improve learning better. Theoretically, this research is expected to contribute ideas in enriching insight into the concept of preventing fanaticism in Islamic schools. It is also hoped that practically it can contribute ideas to problem-solving and become a reference for other researchers related to fanaticism in Islamic schools.

\section{METHODOLOGY}

This study uses quantitative research methods with data collection through filling out questionnaires distributed to respondents, who are around the island of Java. The sampling technique in our study used purposive sampling, which is a non-random technique. Purposive sampling technique is a data collection technique that is not based on random or random but based on considerations to achieve a certain target or focus (Arikunto 2006) in (Khulafaurosyidin and Setiawati 2013). The criteria we mean are educators who have experience in measuring the level of fanaticism in the school environment.

The data collection method that we use is the questionnaire method, namely by distributing questionnaires to respondents. After the data is collected, conclusions are drawn using a deductive mindset. The population in this study was obtained from various agencies. There were 28 respondents from teaching staff who came from 2 Islamic boarding schools, 4 SD/MI, 6 SMP, 2 SMK, 7 SMA, 3 MAN, and 4 Universities. Consisting of 9 men and 19 women. Then respondents were asked to answer 15 questions by choosing one of the options that had been given. The answer choices included strongly agree, agree, disagree, and strongly disagree.

The technique in the operation of data analysis carried out in this study is to provide a set of written questions in the form of multiple-choice questions to make it easier for educators to respond to our questionnaire. The questionnaire used in this case is closed, namely a questionnaire whose answers have been provided so that respondents just choose and answer directly (Sugiyono, 2008 : 1422). After the data is collected, conclusions are drawn using a deductive mindset. The author considers this method suitable to be used to describe the causes and implementation of fanaticism prevention strategies in Islamic schools.

\section{RESULT}

The following are answers from respondents when asked about fanaticism in the school environment:

\begin{tabular}{|c|l|c|c|c|c|}
\hline NO & QUESTION & SA & A & D & SD \\
\hline 1. & $\begin{array}{l}\text { Do you agree with the following statement, that the } \\
\text { triggering factor for fanaticism in schools is the lack of } \\
\text { understanding of the various perspectives of science in } \\
\text { society? }\end{array}$ & $28,6 \%$ & $67,9 \%$ & $3,6 \%$ & $0 \%$ \\
\hline
\end{tabular}




\begin{tabular}{|c|c|c|c|c|c|}
\hline 2. & $\begin{array}{l}\text { Agree or not, that schools with an Islamic background } \\
\text { create a greater chance of fanaticism than formal } \\
\text { schools }\end{array}$ & $3,6 \%$ & $21,4 \%$ & $60,7 \%$ & $14,3 \%$ \\
\hline 3. & $\begin{array}{l}\text { Agree or not, that students tend to be fanatical because } \\
\text { of the influence of their circle of friends }\end{array}$ & $10,7 \%$ & $53,6 \%$ & $32,1 \%$ & $3,6 \%$ \\
\hline 4. & $\begin{array}{l}\text { Do you agree with the following statement, that } \\
\text { organizational mechanisms in schools can influence } \\
\text { fanaticism through the energy generated by the group, } \\
\text { being a positive impact on students? }\end{array}$ & $14,3 \%$ & $35,7 \%$ & $42,9 \%$ & $7,1 \%$ \\
\hline 5. & $\begin{array}{l}\text { Do you agree with the following statement, that } \\
\text { following Islamic organizations such as Rohis, Islamic } \\
\text { associations, Muhammadiyah Islamic associations and } \\
\text { so on is a factor in the formation of fanaticism? }\end{array}$ & $3,6 \%$ & $28,6 \%$ & $50 \%$ & $17,9 \%$ \\
\hline 6. & $\begin{array}{l}\text { Do you agree with Slamet A.'s theory which states that } \\
\text { fanaticism is a form of love that is believed to have } \\
\text { contributed greatly to life? }\end{array}$ & $7,1 \%$ & $39,3 \%$ & $50 \%$ & $3,6 \%$ \\
\hline 7. & $\begin{array}{l}\text { Agree or not, that fanaticism can develop into seeds of } \\
\text { destruction for diversity among students, diversity } \\
\text { among students }\end{array}$ & $17,9 \%$ & $64,3 \%$ & $14,3 \%$ & $3,6 \%$ \\
\hline 8. & $\begin{array}{l}\text { Agree or not, that educational institutions are obliged to } \\
\text { prevent this understanding }\end{array}$ & $21,4 \%$ & $75 \%$ & $3,6 \%$ & $0 \%$ \\
\hline 9. & $\begin{array}{l}\text { Agree or not, that the way to treat bigoted perpetrators } \\
\text { in a school environment is enough with a psychologist }\end{array}$ & $0 \%$ & $14,3 \%$ & $78,6 \%$ & $7,1 \%$ \\
\hline 10. & $\begin{array}{l}\text { Agree or not, during this pandemic, it is difficult for } \\
\text { educational institutions to control their students in } \\
\text { avoiding fanaticism }\end{array}$ & $17,9 \%$ & $60,7 \%$ & $17,9 \%$ & $3,6 \%$ \\
\hline 11. & $\begin{array}{l}\text { Agree or not, that BK is an effective school facility and } \\
\text { facility in preventing this fanaticism }\end{array}$ & $21,4 \%$ & $53,6 \%$ & $21,4 \%$ & $3,6 \%$ \\
\hline 12. & $\begin{array}{l}\text { Do you agree, that counseling and counseling for } \\
\text { students is very important in preventing this } \\
\text { understanding? }\end{array}$ & $28,6 \%$ & $67,9 \%$ & $3,6 \%$ & $0 \%$ \\
\hline 13. & $\begin{array}{l}\text { Do you agree with the following statement, that } \\
\text { education about fanaticism must be carried out by every } \\
\text { educational institution in Indonesia? }\end{array}$ & $25 \%$ & $64,3 \%$ & $10,7 \%$ & $0 \%$ \\
\hline 14. & $\begin{array}{l}\text { In your opinion, have every teaching staff set an } \\
\text { example of behavior that does not lead to fanaticism? }\end{array}$ & $22,2 \%$ & $48,1 \%$ & $29,6 \%$ & $0 \%$ \\
\hline 15. & $\begin{array}{l}\text { In your opinion, is enrolling children in Islamic schools } \\
\text { the right solution in preventing this understanding? }\end{array}$ & $29,6 \%$ & $37 \%$ & $33,3 \%$ & $0 \%$ \\
\hline
\end{tabular}




\section{DISCUSSION}

Based on the results of the respondents' answers that the researchers described above, the forms of fanaticism that exist among students, especially in Islamic schools, are due to a lack of understanding of the various perspectives of science in a society where this statement is supported by 8 respondents who strongly agree and 19 respondents who agree. This statement is also supported by research (Gide 1967) Wolman's opinion on one of the factors that influence the existence of fanaticism, namely ignorance, where stupidity is meant blindly without sufficient knowledge and only following a choice and relying on his beliefs. That is, before we believe and defend our views on something, we must find out more so as not to fall in the wrong direction. Because not everyone understands the various scientific perspectives that exist in social interaction, so not a few speak according to what is seen and are indoctrinated, where the understanding is swallowed raw without finding out the truth. In addition, the influence of the circle of friends also affects the emergence of fanaticism in a person. This opinion was strongly agreed by 3 respondents and agreed by 15 respondents who were also supported by the thoughts of (Clayton, Barlow, dan Ballif-spanvill) which stated that individuals who join groups, membership in groups will lead to individual anonymity.

Feelings of anomie in the individual will reduce self-awareness and interfere with perception. This situation causes individuals to behave in extreme ways, which in normal circumstances is not an individual character. While Festinger explained that the state of anatomy into the process of deindividuation. An individual who has become part of a group is no longer an individual because his identity is lost. Mullen further said that deindividuation destroys normal self-regulation processes and causes aggression. Therefore, in the circle of friends, some lead to positive things or vice versa. Although according to some respondents, he did not agree with the emergence of fanaticism that comes from the circle of friends because not all friendships have a negative impact, this may be due to the principles of trust and solidarity. Apart from this, we as Muslims must be good at sorting and building friendships. According to a hadith of the Prophet Muhammad, he said, "A person who sits (friends) with pious people and bad people, is like making friends with the owner of perfume and a blacksmith. The owner of the perfume will not harm you, you can buy (perfume) from him or at least you get the smell. As for making friends with blacksmiths, if you don't find your body or clothes burned, at least you get a bad smell." (Narrated by Imam Bukhari).

In addition, several respondents agreed that the factor for the formation of fanaticism is that Islamic schools have a higher potential in generating fanaticism than formal schools. But this was denied by some respondents because generally, the form of fanaticism leads to contexts outside of school learning. The point is that the behavior of fanaticism is realized because of groups outside of academia who build or influence someone into being fanatic. Then there are several other reasons, namely students who follow Islamic organizations such as rohis, the Indonesian Islamic Student Movement, Muhammadiyah Islamic associations, and so on are factors in the formation of fanaticism, this statement was denied by some respondents, namely 19 respondents and approved by the rest. There are several reasons why some respondents denied this because joining an Islamic organization tends to have a positive impact on every individual. In addition to gaining experience and other knowledge, a student can also be more active outside the learning process, he can express himself through his ideas, thoughts, ideas that are realized in action to produce inputs and outputs to build the organization. Where this is a way for students as a process of self-development. But apart from the positive impact, some respondents agree that this Islamic organization also has a bad impact.

This is due to the interaction process that exists in organizations that are built for the benefit of student groups or organizations, of course can influence students to be fanatical. In addition, in an organization, of course, some elements are fanatical to the organization they follow and do not seem to want to lose. Another factor is from oneself such as too much love 
for the organization, this also allows the student to carry out an attitude of fanaticism. This is supported by (Orever in Budi, 2004) that such organizations tend to prioritize group sentiments that should be avoided and the emergence of a desire to dominate other groups. Fanaticism is an excessive and irrational enthusiasm for something that exists or as a dedication to a theory, belief, or line of action that determines a very emotional attitude and practically knows no boundaries. When there is an individual or group of students who are fanatical about an organization, of course, he will think that his organization is the best and should be proud of and become a reflection of other organizations. Even a religious organization both outside and inside the school, not a few consider other religious organizations to be lacking good or bad for no good reason. They trust their organization too strongly to judge the truth solely theirs in absolute terms. The explanation regarding organizational mechanisms in schools can influence fanaticism through the energy generated by the group, it can be a positive impact or a negative impact for students, this was agreed by the respondents.

In resolving cases related to fanaticism in Islamic schools, educational institutions are obliged to prevent this understanding. In addition, every educational institution in Indonesia is required to provide counseling related to this fanaticism. Because during this pandemic, it is difficult for educational institutions to control their students in avoiding fanaticism because of the difficulty of interacting face-to-face. And in the process, educators also need to pay attention to learning methods and exemplify a neutral attitude, especially in discussing a sensitive matter for the sake of not creating this understanding. This statement was also agreed upon by the respondents who participated in our study. There are several ways to prevent fanaticism that we present according to our research, namely Islamic counseling guidance, where BK is an effective school facility and facility in preventing this fanaticism. The implementation of this fanaticism prevention strategy was approved by 21 respondents and supported by research from Elvi Yanti (2020) whose research used a strategy employing group guidance, where later an expert in the field of Islamic counseling guidance will explain and relate to religious discussions such as "something that too much is not good" and explain the negative impact it has. Another solution in implementing this prevention which most of the respondents agreed was to enroll children in Islamic schools as the right solution in preventing this understanding. Because according to some respondents this is the right strategy in minimizing this understanding. Because according to some respondents this is the right strategy in minimizing this understanding. The last research related to the importance of preventing fanaticism in an Islamic school environment is by implementing strategies and efforts that can be made by the school in preventing this understanding which was agreed by almost all of the respondents' answers. Because fanaticism can develop into seeds of destruction for diversity among students. In general, this attitude is not able to understand anything that is outside their beliefs, does not want to understand other ideas other than what they believe, and knows no boundaries and is usually extreme. This understanding can also divide harmony between one another and its nature tends to lead to negative things.

Based on the respondents' answers, it can be said that fanaticism in Islamic schools is certainly familiar among students. The attitude that appears from fanaticism itself can be seen from an individual or group of students who reflect attitudes or views in depth so that it is difficult to change or straighten. In a study conducted by Qurrata A'yuna and Said Nurdin, Ibn Taimiyah revealed the principle not to be exposed to ashabiyah (fanatic). If they gather for what Allah and His Messenger have commanded without adding or subtracting, then they are believers, for them what is theirs and for them what is their obligation. (But) if they have added and reduced it like ta'ashub (fanatic) towards people who enter into their hizb with truth or falsehood and reject people who do not enter into their hizb based on truth or falsehood, then this is a disgraceful division. Allah and His Messenger (Majmu' Fatawa) Ibn Taymiyya (Majmu' Syarif) also said, whoever joins a person to become a guardian to the person he makes 
his guardian and is hostile to the person against whom he is an enemy, then he is a type of mujahidin Tatar in the way of Satan. This does not include mujahideen fi sabililah, nor are Muslim soldiers. It is not permissible for people like this to be included in the Muslim army, but they are included in the Shaytan army. Therefore, avoid human nature that tends to act in the name of Islam in building unity and brotherhood which is polluted by ashabiyah. Therefore, Rasulullah SAW warned us all not to fall into the ashabiyah puddle, following the words of the Prophet Muhammad, namely "Whoever fights under the banner of blindness, he is angry because of ashabiyah or calls on ashabiyah or helps based on ashabiyah, then the death of ignorance is death." (HR Muslim).

From Gide and André's research (1967) there is ( Ismail Prkoso, 2013) about the factors that cause fanaticism, namely excessive enthusiasm, meaning someone who has excessive enthusiasm which is not based on common sense but based on uncontrollable emotions. Lack of common sense makes it easy for fanatical people to do unprofessional things, so they do insane things that tend to harm themselves and others. The next factor is the education of a person, who is educated and broad-minded can give rise to the seeds of a more solid attitude or positive fanaticism, and vice versa, dwarf indoctrination can lead to the seeds of fanaticism that tend towards negative fanaticism. The point is that when someone has high education and broad insight into existing knowledge, then a sense of solidarity arises in that person because he can understand and understand and can put things in their place. In contrast to people who are given doctrine continuously because they are not balanced with broad insights, so that it is not selfdevelopment based on the insights, knowledge, and experience they have but forced selfformation based on the doctrine that is given continuously will give rise to the seeds of fanaticism in them.

Opinion (Mubarok, 2010) says that fanaticism is a view or understanding that defends something that cannot be contested for its beliefs. Therefore, in the concept of the problem of fanaticism in the school environment, those who must actively supervise and provide direction are all existing instruments in educational institutions, especially BK services provided by each school. In solving problems, some students need a place to consult, or assistance services called guidance and counseling. The development of counseling theories has long been coloring service strategies and models. At least four major theories in counseling have been developed which are quite coloring services, namely psychodynamics, behaviorism, humanism, and multiculturalism (Sue and Sue, 2003). From the statement above, the concept of preventing fanaticism in the school environment can be drawn, namely applying the spirituality of Islamic counseling. According to Carl Jung, Victor Frankl, Abraham Maslow and Rollo May (in Gladding, 2012) have emphasized the importance of spirituality in counseling. Spirituality is a complex and multi-dimensional understanding, at least including the concept of transcendence, self-actualization, purpose, and purpose in life, wholeness, balance, sacredness, altruism, and awareness of a higher power. Spiritual counseling is a process of assisting individuals so that they can develop their nature as religious beings, behave according to religious values and overcome life problems through understanding, beliefs, and practices of religious ritual worship that they adhere to ( Yusuf, 2007), for example, the approach Pastoral counseling, transpersonal psychology, and Islamic counseling, as well as Islamic counseling.

Counseling is done by developing interactions with each other, increasing intrapersonal and interpersonal awareness, increasing discussion or exchange of ideas, especially for educators and their students. In the study of Islamic counseling, this service assists in solving a problem based on the Qur'an and Hadith to return all problems of an individual or group to the right path and so that the person can live in harmony with the provisions and instructions of Allah SWT. Providing counseling to students is of course very important to increase the potential of mind, psychology, faith, and beliefs and can overcome the problems of life, especially if the student leads to an attitude of fanaticism. In improving Islamic counseling, 
many approaches and theories are needed. Lubis (2003) argues that the foundation of Islamic counseling is values extracted from Islamic teachings. The Qur'an is a source of guidance, advice, and medicine to overcome problems. As contained in (Surah Yunus, 57) "O mankind, indeed there has come to you a lesson from your Lord and a cure for diseases (which are) in the chest and guidance and mercy for those who believe". Islamic counseling brings people closer to their positive nature and helps them not to go the wrong way in fulfilling their lustful impulses so that the impulses are channeled properly, even on the contrary it encourages humans to achieve positive progress (Mubarok, 2012). Thus, a counseling approach that is in line with the Qur'an and Hadith will generate positive energy and help direct you to the right path.

Based on research from Elvi Yanti (2020), this research uses a strategy through group guidance, where later an expert in the field of Islamic counseling will explain and relate to religious discussions such as "something too much is not good" and explains the negative impacts that exist in the community. In it, the results of the research that the author does tend to support the theory because based on research from several Islamic schools that the author has done considers that fanaticism is a negative thing so that schools implement a prevention strategy in the form of BK as an effective school facility and facility in preventing this fanaticism. that fits the theory.

\section{CONCLUSION}

Based on research conducted through filling out questionnaires with closed answers, conclusions can be drawn, namely, the forms of fanaticism that exist in the Islamic school environment can occur due to a lack of understanding of the various perspectives of science in society, this is approved by educators as respondents in this research. In addition, the influence of the circle of friends also affects the emergence of fanaticism in a person, this is approved by most respondents and not approved by some respondents. and there are several other reasons, that joining Islamic organizations such as rohis, Islamic associations, Muhammadiyah Islamic associations, and so on is a factor in the formation of fanaticism, this is approved by some respondents and not approved by some respondents. Because according to the opinion above, organizational mechanisms in schools that can influence fanaticism can be caused by groups, it can be a positive impact on students as well as a negative impact. With the theory presented by Slamet A. that fanaticism is a form of love that is believed to have made a big contribution in life, this is also agreed by most respondents and not approved by some respondents. The educators also do not agree with the statement that schools with an Islamic background give rise to a greater chance of fanaticism than formal schools, although some respondents agree with this.

There are several ways to prevent fanaticism, which we present in the research above, that educational institutions are obliged to prevent this understanding, where respondents agree. In addition, how to treat bigoted perpetrators in the school environment is not enough just by a psychologist. Because during this pandemic, it is difficult for educational institutions to control their students in avoiding fanaticism, this has also been agreed by respondents. Therefore, educators make BK an effective school facility and facility in preventing this fanaticism. The existence of counseling and counseling for students is also very important in preventing this fanaticism. Another solution in implementing this prevention strategy is to include children in Islamic schools. Because according to some respondents this is the right strategy in minimizing this understanding. This must be done because fanaticism can develop into seeds of destruction for diversity among students. And the attitude of fanaticism tends to lead to negative things. Because generally they are not able to understand anything that is outside their belief, do not want to understand other understandings other than what they believe, and knows no boundaries and is usually extreme. This understanding can also divide the harmony between one another.

Based on the results of the research and discussion that have been described, several 
suggestions can be considered, among others, namely educational institutions, this research can be used as an input that can be used as consideration in providing direction, especially in the problem of reducing the level of fanaticism among students. For other researchers, this research can be used as reference material to add insight in conducting further research.

\section{REFERENCES}

V. No and M. Misbah, "INSANIA : Jurnal Pemikiran Alternatif Kependidikan Fanatism in Islamic Education Practices Fanatisme dalam Praktik Pendidikan Islam,” vol. 26, no. 1, pp. 51-64, 2021.

Q. A'yuna and S. Nurdin, "Fanatisme Dalam Tinjauan Psikologi Agama," Suloh, vol. 01, no. 01, pp. 75-82, 2016, [Online]. Available: http://jurnal.unsyiah.ac.id/suloh/article/view/8309.

D. rio Putra, "Fanatisme Dan Taklid (Memfigurkan Sosok Tertentu Secara Eksklusif) Ditinjau Dari Kepemimpinan Sosial,” Int. Semin. Islam. Stud., vol. 1, pp. 250-256, 2019.

A. Khulafaurosyidin and D. Setiawati, "Penerapan Konseling Rasional Emotif Perilaku Untuk Mengurangi Tingkat Fanatisme Terhadap Idola Pada Siswa Smpn 6 Tuban Application of Rational Emotive Behaviors Therapy To Findout the Level of Fanaticism To Popular Idol the Student Class Viii C Smpn 6 Tub,” J. BK Unesa, vol. 3, no. 1, pp. 416-421, 2013.

S. L. Priestnall et al., “No 主観的健康感を中心とした在宅高齢者における 健康関連指標に 関する共分散構造分析Title,” Endocrine, vol. 9, no. May, p. 6, 2020, [Online]. Available: https://www.slideshare.net/maryamkazemi3/stability-of-

colloids\%0Ahttps://barnard.edu/sites/default/files/inline/student_user_guide_for_spss.pdf \%0Ahttp://www.ibm.com/support\%0Ahttp://www.spss.com/sites/dmbook/legacy/ProgDataMgmt_SPSS17.pdf\%0Ahttps://www.nep.

A. C. Sohar, “Metode Q ur' ani Dalam Mengatasi Sikap Fanatik,” pp. 69-86.

B. Herlambang, "Hubungan Antara Kesepian (Loneliness) Dengan Kecenderungan Fanatik Terhadap Hewan Pada Komunitas Pecinta Hewan," J. Chem. Inf. Model., vol. 53, no. 9, p. bab II, 2018.

B. A. B. Iii, "Bab iii metode dan teknik penelitian 3.1," 2008.

A'yuna, Qurrata, and Said Nurdin. 2016. "Fanatisme Dalam Tinjauan Psikologi Agama." Suloh 01 (01): 75-82. http://jurnal.unsyiah.ac.id/suloh/article/view/8309.

Akhmadi, Agus. 2016. "Problema Psikologis Masyarakat Islamic Counselling Approach on Solving." Jurnal Konseling, 375-85.

Gide, André. 1967. “済無No Title No Title No Title.” Angewandte Chemie International Edition, 6(11), 951-952., 5-24.

Herlambang, Boby. 2018. "Hubungan Antara Kesepian (Loneliness) Dengan Kecenderungan Fanatik Terhadap Hewan Pada Komunitas Pecinta Hewan." Journal of Chemical Information and Modeling 53 (9): bab II.

Hidayatullah, Muchammad Syarif. 2018. "( Studi Tematik Surah Al - an ' a $<$ M : 159 Menurut Para."

Iii, B A B. 2008. "Bab Iii Metode Dan Teknik Penelitian 3.1." 
Khulafaurosyidin, Aftukul, and Denok Setiawati. 2013. "Penerapan Konseling Rasional Emotif Perilaku Untuk Mengurangi Tingkat Fanatisme Terhadap Idola Pada Siswa Smpn 6 Tuban Application of Rational Emotive Behaviors Therapy To Findout the Level of Fanaticism To Popular Idol the Student Class Viii C Smpn 6 Tub." Jurnal BK Unesa 3 (1): 416-21.

No, Vol, and Muhammad Misbah. 2021. "INSANIA : Jurnal Pemikiran Alternatif Kependidikan Fanatism in Islamic Education Practices Fanatisme Dalam Praktik Pendidikan Islam” 26 (1): $51-64$.

Priestnall, Simon L., Nancy Okumbe, Linda Orengo, Richard Okoth, Surinder Gupta, Nikita Nakul Gupta, Nikita Nakul Gupta, et al. 2020. "No 主観的健康感を中心とした在宅高齢者における 健康関連指標に関する共分散構造分析Title.” Endocrine $9 \quad$ (May): 6. https://www.slideshare.net/maryamkazemi3/stability-ofcolloids\%0Ahttps://barnard.edu/sites/default/files/inline/student_user_guide_for_spss.pdf \%0Ahttp://www.ibm.com/support\%0Ahttp://www.spss.com/sites/dmbook/legacy/ProgDataMgmt_SPSS17.pdf\%0Ahttps://www.nep.

Putra, Deko rio. 2019. "Fanatisme Dan Taklid (Memfigurkan Sosok Tertentu Secara Eksklusif) Ditinjau Dari Kepemimpinan Sosial.” International Seminar on Islamic Studies 1: 250-56.

Sohar, Aminullah Cik. n.d. "Metode Q Ur’ Ani Dalam Mengatasi Sikap Fanatik," 69-86.

A’yuna, Qurrata, and Said Nurdin. 2016. "Fanatisme Dalam Tinjauan Psikologi Agama." Suloh 01 (01): 75-82. http://jurnal.unsyiah.ac.id/suloh/article/view/8309.

Akhmadi, Agus. 2016. "Problema Psikologis Masyarakat Islamic Counselling Approach on Solving.” Jurnal Konseling, 375-85.

Gide, André. 1967. “済無No Title No Title No Title.” Angewandte Chemie International Edition, 6(11), 951-952., 5-24.

Herlambang, Boby. 2018. "Hubungan Antara Kesepian (Loneliness) Dengan Kecenderungan Fanatik Terhadap Hewan Pada Komunitas Pecinta Hewan." Journal of Chemical Information and Modeling 53 (9): bab II.

Hidayatullah, Muchammad Syarif. 2018. “( Studi Tematik Surah Al - an ' a $<$ M : 159 Menurut Para."

Iii, B A B. 2008. "Bab Iii Metode Dan Teknik Penelitian 3.1."

Khulafaurosyidin, Aftukul, and Denok Setiawati. 2013. "Penerapan Konseling Rasional Emotif Perilaku Untuk Mengurangi Tingkat Fanatisme Terhadap Idola Pada Siswa Smpn 6 Tuban Application of Rational Emotive Behaviors Therapy To Findout the Level of Fanaticism To Popular Idol the Student Class Viii C Smpn 6 Tub." Jurnal BK Unesa 3 (1): 416-21.

No, Vol, and Muhammad Misbah. 2021. "INSANIA : Jurnal Pemikiran Alternatif Kependidikan Fanatism in Islamic Education Practices Fanatisme Dalam Praktik Pendidikan Islam" 26 (1): $51-64$.

Priestnall, Simon L., Nancy Okumbe, Linda Orengo, Richard Okoth, Surinder Gupta, Nikita Nakul Gupta, Nikita Nakul Gupta, et al. 2020. "No 主観的健康感を中心とした在宅高齢者における 健康関連指標に関する共分散構造分析Title.” Endocrine $9 \quad$ (May): 6. https://www.slideshare.net/maryamkazemi3/stability-of- 
colloids\%0Ahttps://barnard.edu/sites/default/files/inline/student_user_guide_for_spss.pdf \%0Ahttp://www.ibm.com/support\%0Ahttp://www.spss.com/sites/dmbook/legacy/ProgDataMgmt_SPSS17.pdf\%0Ahttps://www.nep.

Putra, Deko rio. 2019. "Fanatisme Dan Taklid (Memfigurkan Sosok Tertentu Secara Eksklusif) Ditinjau Dari Kepemimpinan Sosial.” International Seminar on Islamic Studies 1: 250-56.

Sohar, Aminullah Cik. n.d. "Metode Q Ur' Ani Dalam Mengatasi Sikap Fanatik,” 69-86.

M. S. Hidayatullah, “( Studi Tematik Surah Al - an 'a < M : 159 Menurut Para,” 2018. 